\title{
プローブ旅行時間データの取得状況と 旅行時間信頼性指標値の信頼度との関係
}

\author{
関谷 浩孝 1 諸田 恵士 2 ・高宮 進 3 \\ 1正会員 国土交通省国土技術政策総合研究所 道路研究室（†305-0804 茨城県つくば市旭1番地） \\ E-mail: sekiya-h92tb@nilim.go.jp \\ 2非会員 国土交通省国土技術政策総合研究所 道路研究室（†305-0804 茨城県つくば市旭1番地） \\ E-mail: morota-k92ta@nilim.go.jp \\ 3正会員 国土交通省国土技術政策総合研究所 道路研究室（†305-0804 茨城県つくば市旭1番地） \\ E-mail: takamiya-s92tc@nilim.go.jp
}

国道4号上の2区間（約 $31 \mathrm{~km}$ 及び $19 \mathrm{~km} ）$ で1年間に取得されたプローブ旅行時間データを用い，データの 取得状況と旅行時間信頼性指標值の信頼度との関係を分析した。具体的には，仮想的にプローブ旅行時間 データが部分的に取得できていないことを想定した標本データセットを作成し，これから算定される旅行 時間信頼性指標の標本值と真值との差を分析した。この結果，一定の信頼度で旅行時間信頼性指標值を算 定するために必要となるデータ取得日数に関し，次の知見を得た．旅行時間のばらつきの大きな区間では， 必要なデータ取得日数は多くなる。旅行時間のばらつきの大きな区間では，欠測区間長割合が大きくなる と, 必要なデータ取得日数は増加する. 評価対象日数が増加すると, 必要なデータ取得日数が評価対象日 数に占める割合は概ね減少する.

Key Words : travel time reliability, variability, road traffic, probe car data

\section{1. はじめに}

近年，情報通信技術の進展，カーナビゲーションの普 及により，車両の走行位置・時刻情報から算定される DRM 区間 1)単位の旅行時間データ（以下「プローブ旅 行時間データ」という。）を大量に取得できるように なった．国土交通省では，一定の時間帯（7:00〜8:00 の 1 時間帯等），一定の区間（主要交差点間等）て集計し たプローブ旅行時間データを用いて「旅行時間信頼性指 標 ${ }^{2)}$ を算定し，道路交通施策の実施効果を定量的に評

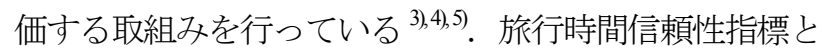
は，旅行時間の日々のばらつきを表す指標で「 $90 \%$ タイ ル旅行時間（10 日に 1 回程度発生寸る混杂侍時の旅行時 間）」や「95\%タイル旅行時間（20日に 1 回程度発生す る混杂倠時の旅行時間）」等がよく用いられる.

ところが，プローブ旅行時間データは全ての時間帯で 取得できているわけではない，例えば，3 ケ月間（平日 60 日）の 7 時台の旅行時間信頼性指標を算定寸る際， 7 時台にプローブ旅行時間データが取得できた日が 10 日 しかない場合もある．当然のことながら，この“10 日 分のデータから算定される旅行時間信頼性指標值” は,
“全日（60 日）のデータから算定される旅行時間信頼 性指標值” と值が異なり, 值の確からしさ，あるいは信 頼度は劣ると推察される。しかし，このことは実務でほ とんど考慮されていない．実務担当者は，事業の実施効 果を示寸指標に旅行時間信頼性指標を用いる際，算定さ れた值が「どの程度の信頼度を有するものか」について, ある程度の相場観を持っておくことがことが望ましいと 考える.

これまで，旅行時間データの数と，これから算定され る指標值の信頼度との関係についての研究がいくつか行 われている. 有吉ら ${ }^{0}$ は, 旅行時間が正規分布に従うこ とを仮定し, 許容誤差率と必要な旅行時間データ数の関 係を分析している，姚ら やは，まず許容誤差 $55 \mathrm{~km} / \mathrm{h}$, 信頼水準 95\%で旅行時間の標準偏差を算定するために必 要となるデータ数を標準偏差式 ${ }^{8}$ を用いて分析し, 観測 された旅行時間データから算定される指標值の信頼度を 評価している.これらの研究は, 統計学で用いられる分 布等に基づき，データ数と信頼度との関係を分析してい る.これに対し本研究では, 実際に観測されたプローブ 旅行時間データを用いて，仮想的にプローブ旅行時間 データが部分的に取得できていないことを想定した標本 
データセットを作成し，これから算定される旅行時間信 頼性指標の標本值と真值との差を分析する等，より実証 的な研究を行った.

また，プローブ旅行時間データを用いた同様の分析を 橋本ら ${ }^{9}$ が行っている. この研究では, DRM 区間単位 で 1 ケ月間（平日 20 日）の旅行時間の標準偏差を正し く算定するために必要となるプローブ旅行時間データの 取得日数を分析している. しかし，事業実施効果の評価 は，通常，DRM 区間単位でなく，主要な交差点間等， ある程度距離のある区間を対象に行われる ${ }^{3 / 4,5) . こ の た ~}$ め本研究では, 複数の DRM 区間で構成される OD 区間 を分析の対象とし，また，旅行時間の標準偏差だけでな く, 90\%タイル旅行時間や $95 \%$ タイル旅行時間等，実務 でよく用いられる旅行時間信頼性指標を対象に信頼度の 分析を行った.さらには，旅行時間のばらつきの大きな 区間と小さな区間の 2 区間を分析対象とし，一定の信頼 度で旅行時間信頼性指標を算定するために必要となるプ ローブ旅行時間データの取得日数について比較を行った。 本稿では, 分析方法の概要と得られた主な知見を紹介寸 る.

\section{2. 使用データ}

\section{a) プローブ旅行時間データ}

2011年10月1日から2012年9月30日の平日7時台に取得さ れたプローブ旅行時間データを使用した。 ただし，年末 年始，ゴールデンウィーク及びお盆期間中の平日，休日 に挟まれた平日並びに悪天候の日（大雨，降雪，台風） は除いた（分析対象は234日）。これは，事業実施効果 を評価する際，こういった特異な日を対象としないこと が多いためである。それぞれの日の7時台（10月1日の7 時台等）に1件でもプローブ旅行時間データが取得され ていれば，この值をこの日を代表する旅行時間とした。 7時台に複数のプローブ旅行時間データが取得された場 合は，それらの平均值を用いた。

なお，プローブ旅行時間データは，直進車だけでなく 右折車と左折車の旅行時間データも含む. つまり, 右折 待ちに要した時間も含むデータである.このため, 本研 究で扱うOD区間旅行時間データ (2章c) 参照) は, 直 進車がOD間を実際に移動する際の旅行時間より大きい 值となる可能性がある.

b) OD区間

交通量が多く, プローブ旅行時間データが豊富に取得 されていた国道4号上りの2つのOD区間（図-1）を分析 対象とした. 両区間の概要を表-1に示寸．OD区間1及び OD区間2は，それぞれ92及び87のDRM区間で構成されて いる.

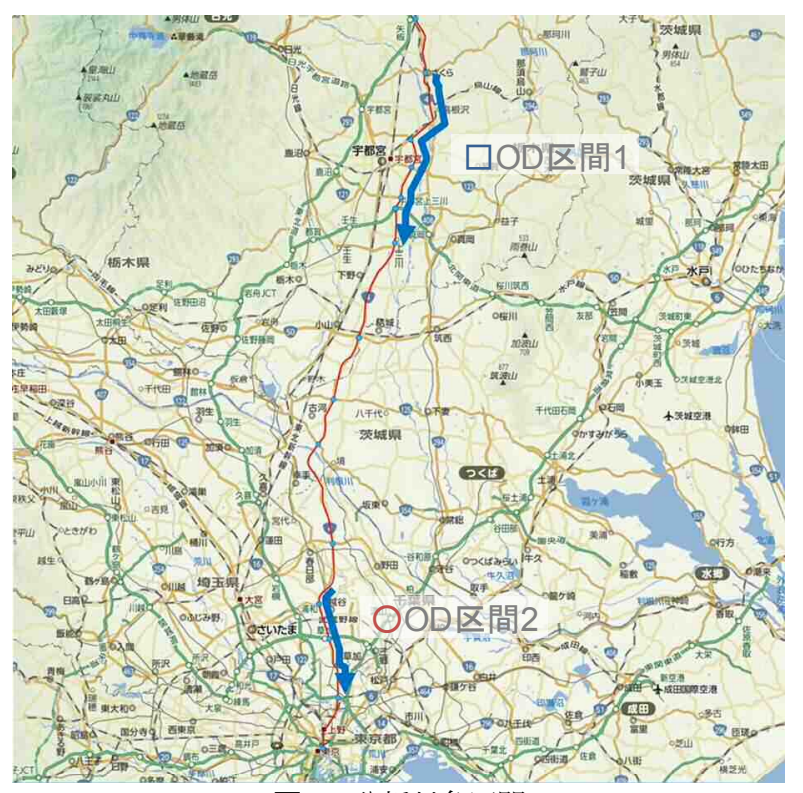

図-1 分析対象区間

表-1 OD区間 1 とD区間2の概要

\begin{tabular}{lcc}
\hline & OD区間1 & OD区間2 \\
\hline 起点 & 国道293号交差点 & 4号現道交差点 \\
終点 & 国道352号交差点 & 首都高中央環状 \\
距離 $(\mathrm{km})$ & 31.0 & 18.8 \\
車線数 & 4車線 $($ 約 $13 \mathrm{~km})$ & 4車線(約14km) \\
& 6車線( $($ 約 $17 \mathrm{~km})$ & 6車線 $($ 約 $5 \mathrm{~km})$ \\
信号交差点数 & $70(2.2 / \mathrm{km})$ & $47(2.5 / \mathrm{km})$ \\
DRM区間数 & $92(337 \mathrm{~m} /$ 区間 $)$ & $87(216 \mathrm{~m} /$ 区間 $)$ \\
\hline
\end{tabular}

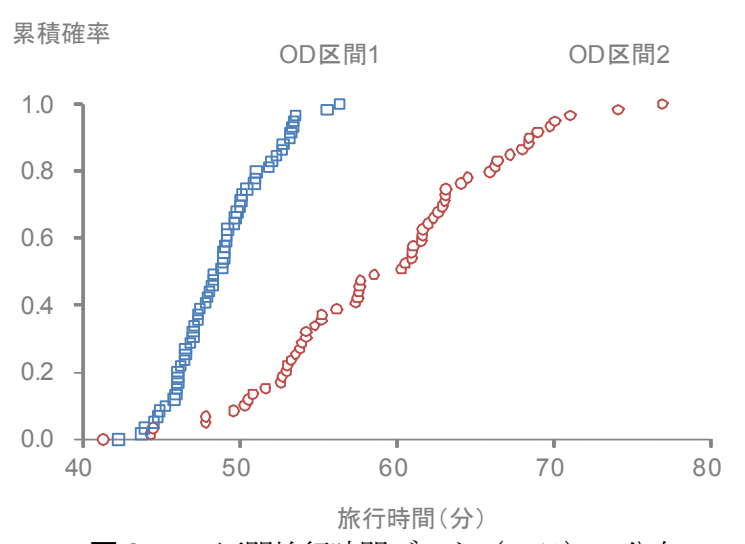

図-2 OD 区間旅行時間データ $(60$ 日）の分布

表-2 60 日分のOD区間旅行時間データから算定した旅行時 間信頼性指標值

\begin{tabular}{|c|c|c|c|}
\hline & OD区間1 & & OD区間2 \\
\hline 口標準偏差 & 3.0 分 & $<$ & 7.6分 \\
\hline ×95\%タイル值 & 53.5分 & $<$ & 70.1分 \\
\hline \90\%タイル值 & 53.2分 & $<$ & 68.5分 \\
\hline ×中央值 & 48.6分 & $<$ & 59.4分 \\
\hline o平均值 & 48.8分 & $<$ & 59.0 分 \\
\hline (平均旅行速度) & $(38.1 \mathrm{~km} / \mathrm{h})$ & $>$ & $(19.1 \mathrm{~km} / \mathrm{h})$ \\
\hline 最大值 & 56.4分 & $<$ & 77.0分 \\
\hline 最小值 & 42.3分 & $>$ & 41.3分 \\
\hline Buffer Time $90 \%$ & 4.45分 & $<$ & 9.49分 \\
\hline Buffer Time Index $90 \%$ & 0.09 & $<$ & 0.16 \\
\hline
\end{tabular}




\section{c) OD区間旅行時間データ}

各OD区間で，OD区間内の全てのDRM区間において, 同一日の7時台にプローブ旅行時間データが取得されて いた日がOD区間1では215日（分析対象234日の92\%）， OD区間2では96日（分析対象234日の41\%）あった。これ らの日を対象に，各DRM区間で取得されたプローブ旅 行時間データの単純和により, OD区間の旅行時間（以 下「OD区間旅行時間データ」という。）を算定した.

このうち，日付の新しいものから順に60日分のOD区 間旅行時間データを抽出した。この分布を累積確率の形 式で図-2に示す。これから算定した旅行時間信頼性指標 值を表-2に示寸，OD区間1はOD区間2に比心゙，平均旅行 速度が大きく（OD区間 $1 ： 38.1 \mathrm{~km} / \mathrm{h} ， \mathrm{OD}$ 区間 $2 ：$ $19.1 \mathrm{~km} / \mathrm{h}$ )， Buffer Time Index $90 \%{ }^{10)}$ が小さい（OD区間1： 0.09，OD区間 $2 ： 0.16 ）$ 。ここでBuffer Time Index $x_{90 \%}$ とはば らつきの度合いを表寸指標で「（90\%タイル旅行時間一 平均旅行時間） $\div$ 平均旅行時間」で算定される。つまり, OD区間1はOD区間2より混雑の度合が小さく，かつ旅行 時間のばらつきが小さい.

\section{OD区間旅行時間データの取得日数と旅行時間信 頼性指標值の信頼度との関係}

60 日のうち一部の日でしか OD 区間旅行時間データが 取得できていないケースを想定し，算定される旅行時間 信頼性指標値（標準偏差，95\%タイル値，90\%タイル值， 中央值及び平均值）が，真値とどの程度異なるかを分析 した．ここでの真值は，表-2に示した「全日（60日） の OD区間旅行時間データから算定した值」とした.

\section{(1) 標本データセットの作成及び標本值の算定}

60 日のうち，2～59 日分の OD 区間旅行時間データが 取得できたケースを想定し，標本データセットを作成し た．以下，OD区間 2 で 60 日のうち 10 日分の OD 区間 旅行時間データが取得できたケース（10 日/60 日）を例 に示す.

図-3に示寸とおり，2章 c)に示した 60 日の OD区間旅 行時間データの中から 10 日分をランダムに選定し, 旅 行時間信頼性指標の標本值を算定した. これを 1,000 回 繰り返し，1,000 個の標本值を算定した [禣注]（表-3）. これを累積確率の形式で示すと図-4のとおりとなる.

\section{(2) 旅行時間信頼性指標値の信頼度の算定}

標本データセットから算定した旅行時間信頼性指標の 標本值が「真值の 95\% 105\%内」となる場合に「正し く算定できた」と判定した. 1,000 個の標本値のうち 「正しく算定できた」標本值の割合を「信頼度」とした.

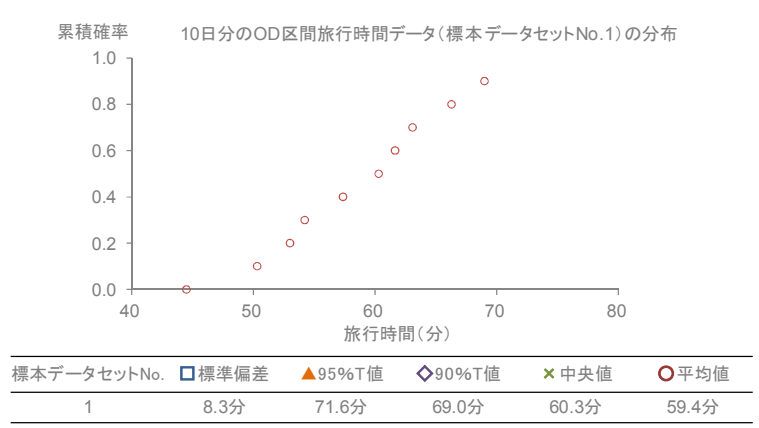

図-3 標本データセット（10日分）の分布及び旅行時間信 頼性指標の標本值

表-3 標本データセット（10日分）から算定された旅行時 間信頼性指標の標本值（1,000個）

\begin{tabular}{|c|c|c|c|c|c|}
\hline 標本データセットNo. & 口標準偏差 & A95\%T值 & $\diamond 90 \%$ T値 & $\times$ 中央値 & O平均值 \\
\hline 1 & 8.3分 & 71.6分 & 69.0分 & 60.3分 & 59.4分 \\
\hline 2 & 7.2分 & 69.0分 & 67.9分 & 59.2分 & 59.0 分 \\
\hline 3 & 8.5分 & 72.1分 & 69.8分 & 60.9分 & 61.7分 \\
\hline 4 & 5.8分 & 66.3分 & 64.2分 & 57.0 分 & 55.9分 \\
\hline 5 & 6.7分 & 68.2分 & 66.7分 & 58.2分 & 58.1分 \\
\hline . & . & . & . & . & . \\
\hline . & . & . & . & . & . \\
\hline 1000 & 8.0分 & 70.6分 & 69.0分 & 60.2 分 & 61.0分 \\
\hline
\end{tabular}

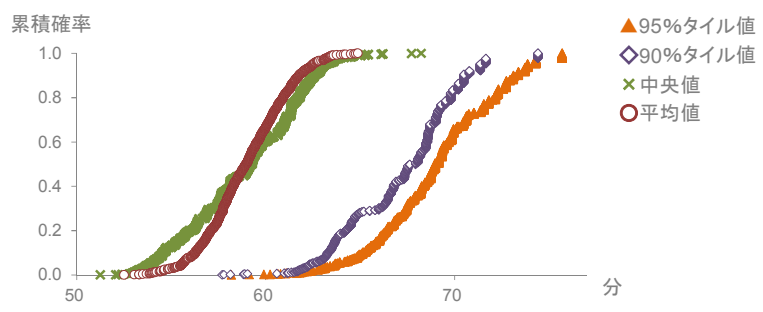

図-4 標本データセット（10日分）から算定された旅行時 間信頼性指標の標本值 $(1,000$ 個) の分布

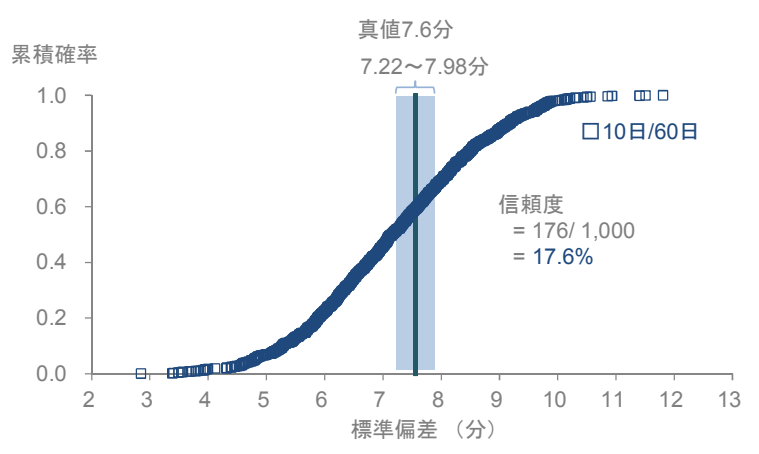

図-5＼cjkstart標準偏差の信頼度の算定例（10日/60日）

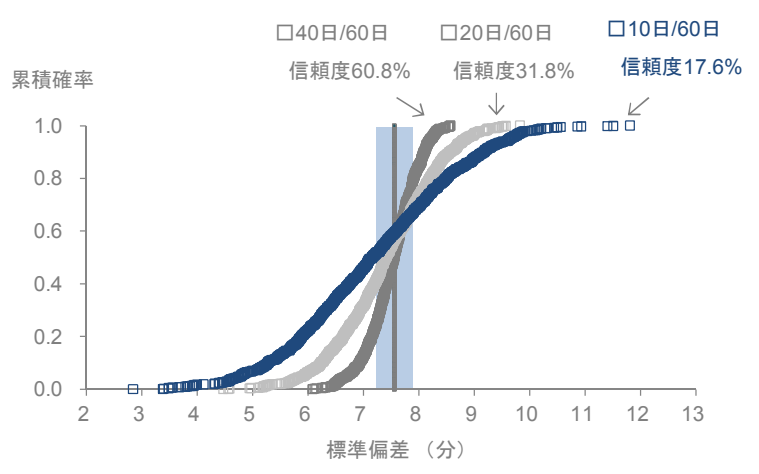

図-6 標準偏差の信頼度の算定例（20日/60日，40日/60日） 
標準偏差についての信頼度の算定例を図-5 に示す．標 本データセットから算定した 1,000 個の標本值のうち, 真值（7.6分）の 95\% 105\%内（7.22～7.98 分）となるも のが 176 個あった。これより信頼度は 17.6\%（=176／ 1,000） と算定される. これは次を意味する：「全日（60 日）のうち 10 日分の OD 区間旅行時間データが取得で きると，17.6\%の確率で標準偏差を真值の 95\% 105\%の 值として正しく算定することができる. 残りの $82.4 \%$ の 確率で，真值の $\pm 5 \%$ 以上の誤差を有する值として算定 される.」

OD 区間旅行時間データの取得日数を「20日/60 日」 及び「40日/60 日」として同様の算定を行った．これを 図-6に示す．取得日数が増加すると（10 日 $\rightarrow 20$ 日 $\rightarrow 40$ 日），標本データセットから算定された 1,000 個の標本 值の分布が真值（7.6 分）に近づき, 信頼度が増加して いる.

OD 区間 1 及び OD 区間 2 において，OD 区間旅行時間 データの取得日数を「2 日/60日」〜「59日/60日」とし て, 旅行時間信頼性指標值（標準偏差, 95\%タイル值, 90\%タイル値, 中央值及び平均值）の信頼度を算定した。 横軸を「OD 区間旅行時間データの取得日数」, 縦軸を 「旅行時間信頼性指標值の信頼度」としてプロットする と図-7のとおりとなる.

\section{(3) $90 \%$ の信頼度で旅行時間信頼性指標値を正しく算定} するために必要なOD区間旅行時間データの取得日数 図-7から，90\%の信頼度で旅行時間信頼性指標值を正 しく算定寸るために必要となるOD区間旅行時間データ の取得日数を整理した. これを図-8に示す.

\section{a) OD区間 1 とOD区間 2 の比較}

90\%の信頼度で旅行時間信頼性指標值を算定しょうと すると, OD 区間 2 では, OD 区間 1 より多くの日数分 の OD 区間旅行時間データが必要となる（ただし，標準 偏差の夕同数）。例えば，90\%タイル旅行時間を $90 \%$ の 信頼度で算定しようとすると，OD 区間 1 では 15 日分 (60 日の $25 \%)$ の OD 区間旅行時間データがあればよい. これに対し，OD区間 2 では 21 日分（60日の 35\%）必要 になる。これは，OD 区間 2 の旅行時間のばらつきが OD 区間 1 より大きいためである（2章参照）。

\section{b) 旅行時間信頼性指標間の比較}

必要となるOD区間旅行時間データの取得日数は，旅 行時間信頼性指標間で大きく異なる．例えば，標準偏差 を90\%以上の信頼度で算定するためには，OD区間1及び OD区間2ともに 53 日分 $(60$ 日の $88 \%)$ のOD区間旅行時間 データが必要となる.これは, 前節で示した $90 \%$ タイル 旅行時間を算定するために必要な日数（区間1：15日分

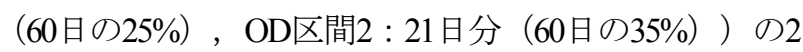
倍を超える。必要となるOD区間旅行時間データの取得
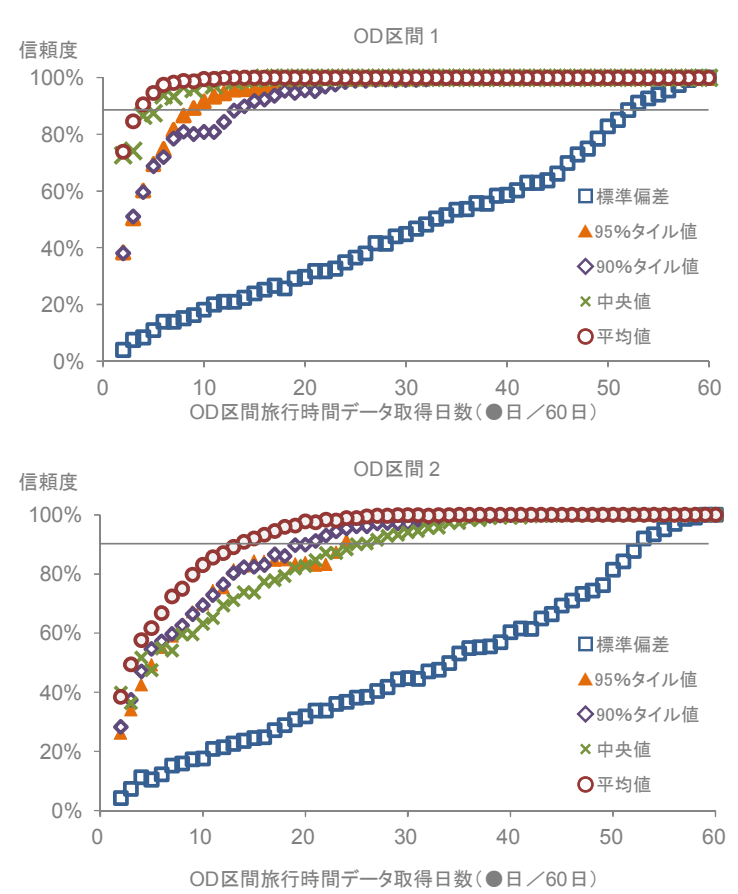

図-7 OD 区間旅行時間データ取得日数（2〜60 日）と信頼度 との関係

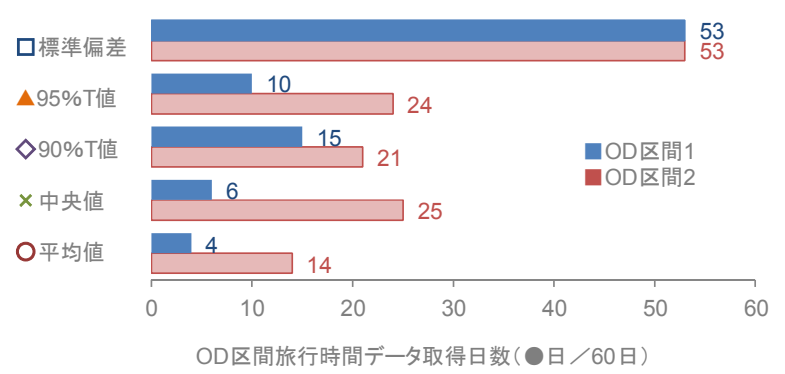

図-8 旅行時間信頼性指標值を $90 \%$ 以上の信頼度で算定するた めに必要な OD 区間旅行時間データの取得日数 $(\bullet 日 / 60$ 日）
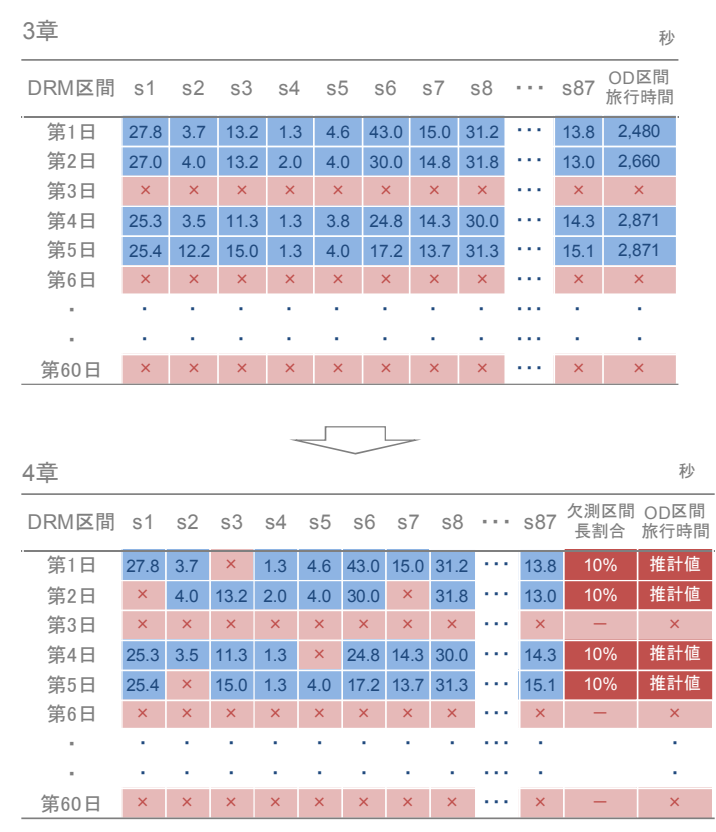

:プローブ旅行時間データが取得できているDRM区間 :プローブ旅行時間データが取得できていないとするDRM区間

図-9＼cjkstart想定するデータ取得状況の比較 
日数が最も少ないのは「平均旅行時間」である，OD区 間1では4日分 $(60$ 日の $6.6 \%), \mathrm{OD}$ 区間2では14日分 $(60$ 日の $23 \% ） の \mathrm{OD}$ 区間旅行時間データが取得できれば, 90\%の信頼度で平均旅行時間を算定することができる.

\section{DRM区間単位の欠測状況を考慮した分析}

図-9に示すように3章では，標本データセットを作成 する過程で，OD区間旅行時間データが取得できたとす る日（例えば，3章(1)に示した60日のうちの10日分のOD 区間旅行時間データ。図-9の第1日，第2日等。）では, OD区間を構成する全てのDRM区間においてプローブ旅 行時間データが取得できているとした．これに対し4章 では，上記の「10日分のOD区間旅行時間データ」にお いて，OD区間を構成するDRM区間の一部でプローブ旅 行時間データが取得できていないことを想定した分析を 行う.

\section{(1) 標本データセットの作成}

仮想的にプローブ旅行時間データが取得できていない （欠測している）とするDRM区間（以下「仮想欠測区 間」という。）の延長がOD区間長に占める割合（以下 「久測区間長割合」という。）を，10\%，20\%，30\%， 40\%及び50\%の5パターン設定した．3章(1)で作成した 1,000個の標本データセットそれぞれにおいて，5パター ンの欠測区間長割合となるよう，「仮想欠測区間とする DRM区間」をランダムに選定した．仮想欠測区間にお ける旅行時間は，実際に取得されたプローブ旅行時間 データの值でなく，式(1)から算定される值とした.

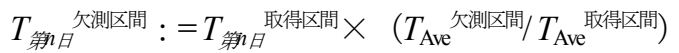

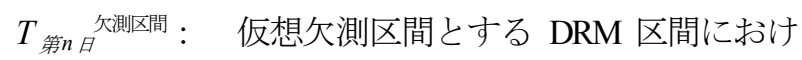
る第 $n$ 日の旅行時間

$T_{\text {第n日 }}$ 取得区間 $^{\text {想欠測区間としない DRM 区間で第 }}$ $n$ 日に取得されたプローブ旅行時間 データ

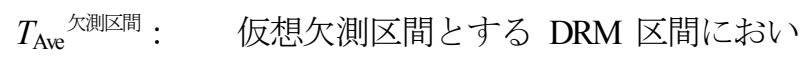
て取得されたプローブ旅行時間データ の 60 日間の平均值

$T_{\mathrm{Ave}}{ }^{\text {㥂区間 }}$ ： 仮想欠測区間としない DRM 区間にお いて取得されたプローブ旅行時間デー タの 60 日間の平均值
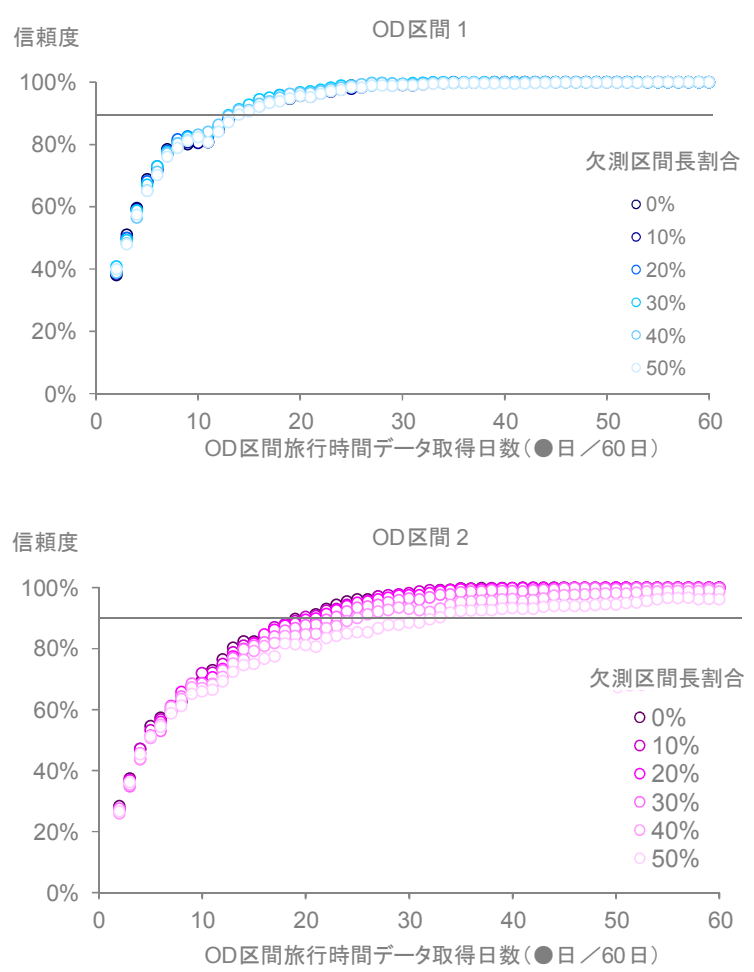

図-10 OD 区間旅行時間データの取得日数（2６0 日）と $90 \%$ タイル旅行時間の信頼度との関係

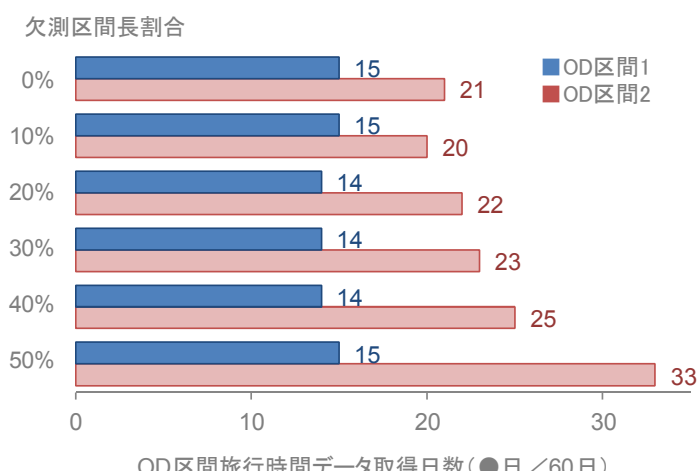

図-11 90\%タイル旅行時間を信頼度 90\%以上で算定するた めに必要な OD 区間旅行時間データの取得日数（。 日/60日）

\section{(2) $90 \%$ の信頼度で $90 \%$ タイル旅行時間を正しく算定す るために必要なOD区間旅行時間データの取得日数}

(1)で作成した標本データセットを用い，3章(2)に示し た方法で旅行時間信頼性指標值の信頼度を算定した. OD区間旅行時間データの取得日数と $90 \%$ タイル旅行時 間值の信頼度との関係を図-10に示す。これから，90\% の信頼度で $90 \%$ タイル旅行時間值を正しく算定するため に必要となるOD区間旅行時間データの取得日数を整理 した.これを図-11に示す.

OD 区間 2 では，欠測区間長割合が増加すると，必要 となる OD 区間旅行時間データの取得日数は増加してい る．例えば，欠測区間長割合が 50\%になると，欠測区間 長割合が $0 \%$ ケース（21日）より 12 日多い 33 日分の 
OD 区間旅行時間データが必要となる. 一方 OD 区間 1 では，欠測区間長割合が増加しても，必要となる OD区 間旅行時間データの取得日数はほとんど変化していない これは，3 章(3)で示した理由と同様，OD 区間 2 の旅行 時間のばらつきが OD 区間 1 より大きいことが主な要因 であると考える（2章参照）。

\section{5. 評価対象日数20日及び96日のケースとの比較}

3章及び4章では，評価対象日数を60日としたケースの 分析結果を示した．本章では，評価対象日数を20日及び 96日として旅行時間信頼性指標を算定するケースについ て同様の分析を行い，結果を比較する。ここでは旅行時 間のばらつきの大きいOD区間2を分析対象とする.

\section{(1) 評価対象日数20日，96日のOD区間旅行時間データ}

2章で示した96日分のOD区間旅行時間データのうち， 新しい日付のものから順に20日分を抽出した。 この20日 分と96日分のOD区間旅行時間データの分布を図-12に示 す。これらから算定した旅行時間信頼性指標值を，表-2 に示した評価対象日数60日のケースの值とともに表-4に 示す. 評価対象日数が増加すると, 標準偏差やBuffer Time Index 90\%の值が増加し，旅行時間のばらつきが大き くなっている.これは，評価対象日数を増やすと（20日 $\rightarrow 60$ 日 $\rightarrow 96$ 日），平均的な值から大きくはずれるOD区 間旅行時間データが含まれるようになり，OD区間旅行 時間データの最大值と最小值の差が大きくなったことに よる．例えば，評価対象日数を20日とするケースでは， 最大值（77.0分）と最小值（53.0分）の差は24.0分である. 評価対象日数を60日とするケースでは，最大值（77.0 分）には変化がないものの, 最小值は41.3分となり, 最 大值との差は35.7分に増加する. 評価対象日数を96日と するケースでは，105.6分のOD区間旅行時間データが含 まれるようになり，最大值と最小值の差は64.3分となる.

\section{(2) 必要データ取得日数割合}

3章に示した方法を用いて，評価対象日数を 20 日及び 96日とするケースについても標本データセットを作成し， 一定の信頼度（90\%，95\%及び99\%）で90\%タイル旅行時 間を算定するために必要となるOD区間旅行時間データ の取得日数を算定した。 なお，評価対象日数 20 日及び 96 日のケースの真值は，それぞれ69.0分及び70.6分とした (表-4に示す $90 \%$ タイル值) . 算定結果を図-13に示す. この日数が評価対象日数に占める割合（以下「必要デー タ取得日数割合」という。）を算定した。これを図-14 に示す.

評価対象日数が増加すると（20日 $\rightarrow 60$ 日 $\rightarrow 96$ 日），
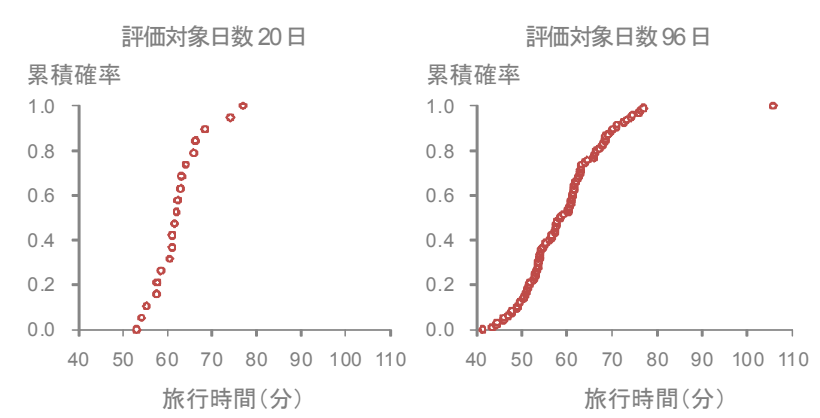

図-12 評価対象日数 20 日及び 96 日の OD 区間旅行時間デー 夕の分布 $(\mathrm{OD}$ 区間 2)

表-4 評価対象日数20日，60日及び96日における旅行時時間 信頼性指標值 (OD区間2)

\begin{tabular}{lccc}
\hline 評価対象日数 & 20 日 & 60 日 & 96 日 \\
\hline 口標準偏差 & 6.0 分 & 7.6 分 & 9.5 分 \\
$\triangle 95 \%$ タイル值 & 74.3 分 & 70.1 分 & 74.2 分 \\
$\triangle 90 \%$ タイル值 & 69.0 分 & 68.5 分 & 70.6 分 \\
×中央值 & 61.8 分 & 59.4 分 & 58.5 分 \\
○平均値 & 62.3 分 & 59.0 分 & 59.4 分 \\
最大值 & 77.0 分 & 77.0 分 & 105.6 分 \\
最小值 & 53.0 分 & 41.3 分 & 41.3 分 \\
Buffer Time $_{90 \%}$ & 6.7 分 & 9.49 分 & 11.2 分 \\
BufferTimeIndex $_{90 \%}$ & 0.11 & 0.16 & 0.19 \\
\hline
\end{tabular}

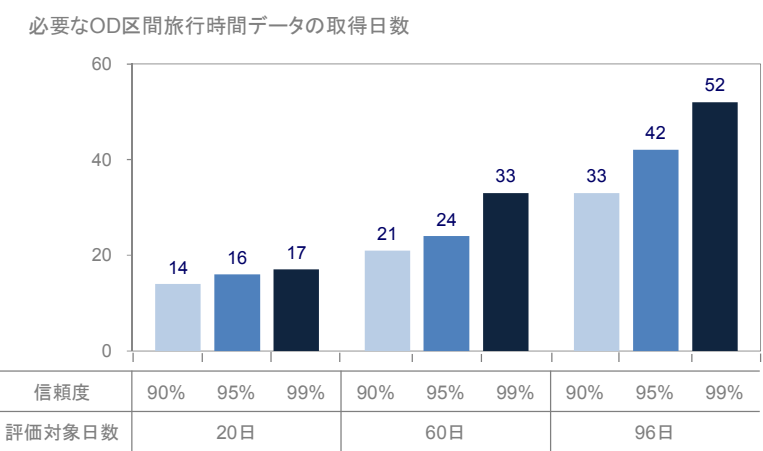

図-13 90\%タイル旅行時間を一定の信頼度（90\%，95\%及び 99\%) で算定するために必要な OD 区間旅行時間デー 夕の取得日数（OD区間 2)

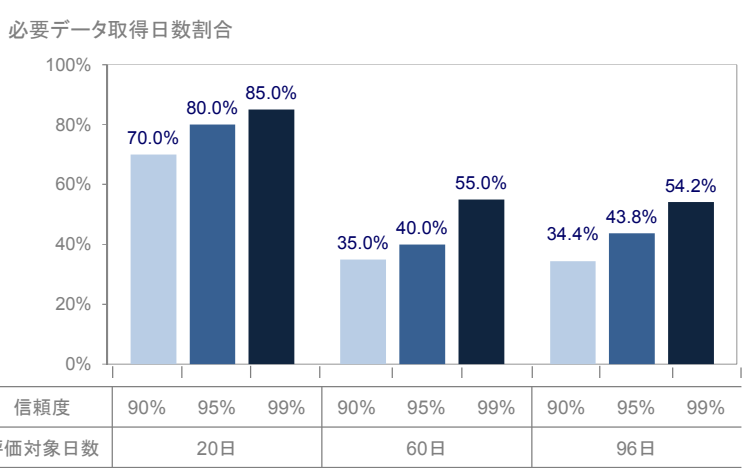

図-14 90\%タイル旅行時間を一定の信頼度（90\%，95\%及び 99\%) で算定するために必要な OD 区間旅行時間デー タの取得日数割合（OD区間 2) 
必要なデータ取得日数は増加する（図-13）が, 必要 データ取得日数割合は概衫減少している（図-14）。

評価対象日数を 20 日から 60 日にすると, 必要データ 取得日数割合が大幅に減少している．例えば，90\%の信 頼度を確保しようとすると, 評価対象日数 20 日での必 要データ取得日数割合は $70.0 \%$, 評価対象日数 60 日で は $35.0 \%$ でる。一方, 評価対象日数を 96 日とする

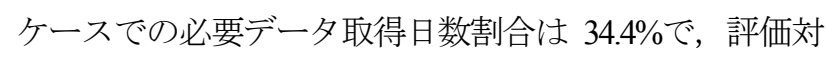
象日数 60 日での值 $(35.0 \%)$ との差は小さい.これは, 評価対象日数 96 日での旅行時間のばらつきが, 評価対 象日数 60 日より大きいことが一因であると考える. 例 えば，評価対象日数96 日での Buffer Time Index $90 \%$ （0.19）は, 評価対象日数 60 日での值 (0.16) より大き い. また図-12 を見ると, 評価対象日数 96 日では, OD 区間旅行時間データの最大值（105.6 分）が 1 つだけ他 より際立って大きな值となっている．このことも，評価 対象日数 96 日と評価対象日数 60 日の必要データ取得日 数割合の差が小さいことの要因であると考える.

\section{(3)「評価対象日数」と「必要なOD区間旅行時間データ} の取得日数」との関係を表す式

「評価対象日数」と「 $90 \%$ タイル旅行時間を一定の信 頼度（90\%，95\%及び 99\%）で算定するために必要とな る OD区間旅行時間データの取得日数」との関係を表寸 式を推定した. 前項で示したように, 評価対象日数が増 加すると必要データ取得日数割合は概ね減少することか ら, 線形近似に加え, 上に凸となる二次多項式, 対数式 及び累乗式を推計に用いた．結果を図-15に示す．線形 近似式は，4 つの近似式のうち決定係数が最大 $(0.9936$

(信頼度 99\%)，0.9393（信頼度 95\%），0.9675（信頼度 90\%））で，最もあてはまりが良い.

これを用いることにより，任意の評価対象日数（20 日〜100 日程度）において算定された $90 \%$ タイル旅行時 間の信頼度を把握することができる．例えば，40日

(2 ケ月間の平日の日数) のうち，25日を超える日数分 のプローブ旅行時間データが取得できていると，99\%以 上の信頼度で 90\%タイル旅行時間を算定することができ る（図-15, 線形近似式, 信頼度 $99 \%$ のラインで $x=40$ に対応する $y=25.4 ）$.

ただし，図-15 に示した式は，いずれも評価対象日数 20 日，60日及び 96 日の 3 点のデータから推定されたも のであるため, 十分な信頼度を有しているとはいえない. 今後, 同じ区間で異なる期間に取得された旅行時間デー タや，異なる区間で取得された旅行時間データから同様 の分析を行うことにより，多数のデータ（“評価対象日 数” と “必要な OD区間旅行時間データの取得日数” に 関するデータ）を取得し，信頼度の高い関係式を構築す る必要がある。
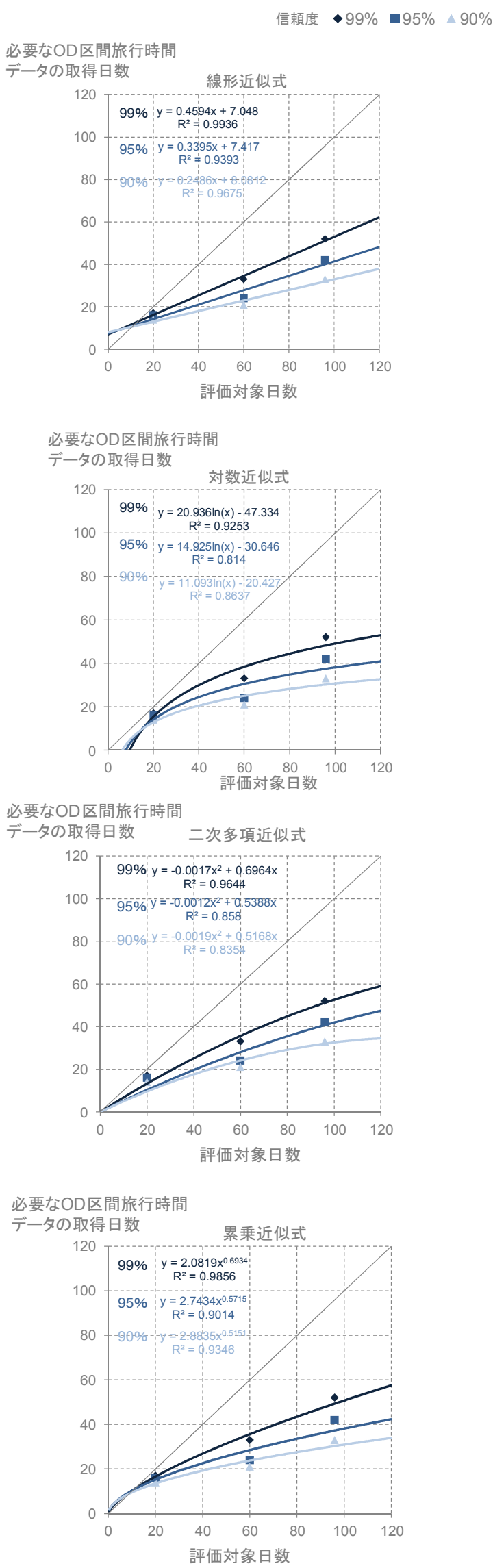

図-15「評価対象日数」と「90\%タイル旅行時間を一定の 信頼度（90\%，95\%及び 99\%）で算定するために 必要な OD 区間旅行時間データの取得日数」との 関係を表す式 


\section{6. 考察}

\section{(本研究の分析方法)}

本研究では, 正規分布等の統計学上の分布に拠らず, 観測されたプローブ旅行時間データの分布から「一定の 信頼度で旅行時間信頼性指標值を算定するために必要な データ取得日数」等を分析した.このため, これら「必 要なデータ取得日数」等を, より実際の道路交通に即し た值として算定することができた，しかしながら，連続 する複数のDRM区間においてプローブ旅行時間データ が取得できているOD区間は限られている。このため本

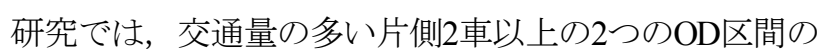
みを対象に分析を行っており,「必要なデータ取得日 数」等の值そのものを，任意の区間に適用できる汎用性 のあるものとして示すことができないという課題を有す る.

このことから, 本研究で得られた一般的知見は次に示 す3つの傾向に留まる.

・旅行時間のばらつきの大きな区間では，一定の信頼 度で旅行時間信頼性指標值を算定するために必要な データ取得日数は多くなる.

・旅行時間のばらつきの大きな区間では，欠測区間長 割合が大きくなると，一定の信頼度で旅行時間信頼 性指標值を算定するために必要なデータ取得日数は 増加する.

·評価対象日数が増加すると（20日 $\rightarrow 60$ 日 $\rightarrow 96$ 日）， 必要データ取得日数割合 ( “一定の信頼度で旅行時 間信頼性指標值を算定するために必要なデータ取得 日数”が “評価対象日数”に占める割合）は概数減 少する.

プローブ旅行時間データ数は年々増加傾向にあること からも，今後，汎用性のある成果を得ることができるよ う, 異なる道路構造の区間（片側1車，信号交差点密度 の小さい区間）も含め，多数のOD区間を対象に同様の 分析を行う必要がある.

(信頼度の要求水準)

本研究では，一定の信頼度で旅行時間信頼性指標を正 しく算定するために必要となるデータ取得日数等の分析 を行った. しかし，実務において旅行時間信頼性指標を 算定しょうとする際に, どの程度の信頼度が必要となる かといった「信頼度の要求水準」については未検討であ る. 今後, 対象とする道路の性格や指標算定の目的に応 じた信頼度の要求水準についての考え方を整理する必要 がある。

(信頼度の評価方法)

本研究では「標本值が真值の $95 \%$ ～105\%内となる確 率」を信頼度とした。しかし，信頼度を評価する方法は 平均絶対誤差率 (MAPE, 式(2)) や二乗平均誤差
（RMSE，式(3)）をはじめ，他にも複数ある.これらを 用いた算定結果を図-16及び図-17に示す（評価対象日数 60 日，OD区間2）。今後, 複数の評価方法を組み合わせ る等, 多角的に信頼度を評価する方法を検討する必要が ある。

平均絶対誤差率

$$
M A P E=\frac{\sum_{i=1}^{N}\left|X-x_{i}\right| / N}{X}
$$

$X:$ 真值

$x_{i}: i$ 番目標本值 $(i=1 \sim 1000)$

$N$ : サンプル数 $(1,000)$

二乗平均誤差 (RMSE)

$$
R M S E=\sqrt{\sum_{i=1}^{N}\left(X-x_{i}\right)^{2} / N}
$$

$X:$ 真值

$x_{i}: i$ 番目標本值 $(i=1 \sim 1000)$

$N$ : サンプル数 $(1,000)$

平均絶対誤差率 (MAPE)

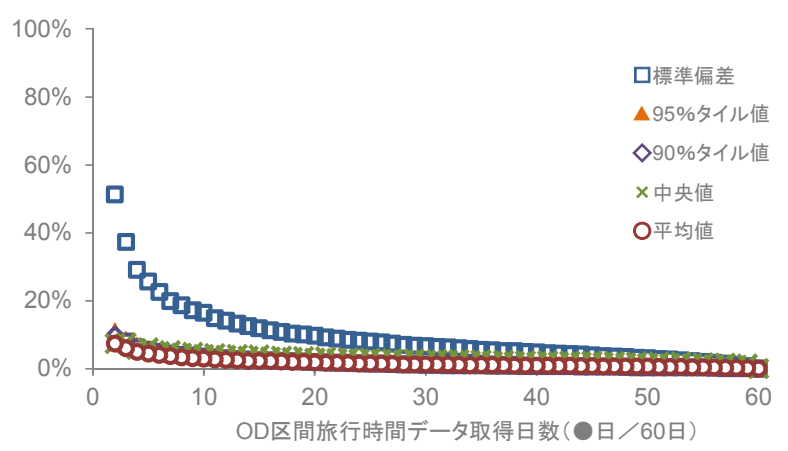

図-16 OD 区間旅行時間データ取得日数と平均絶対誤差率 (MAPE) との関係

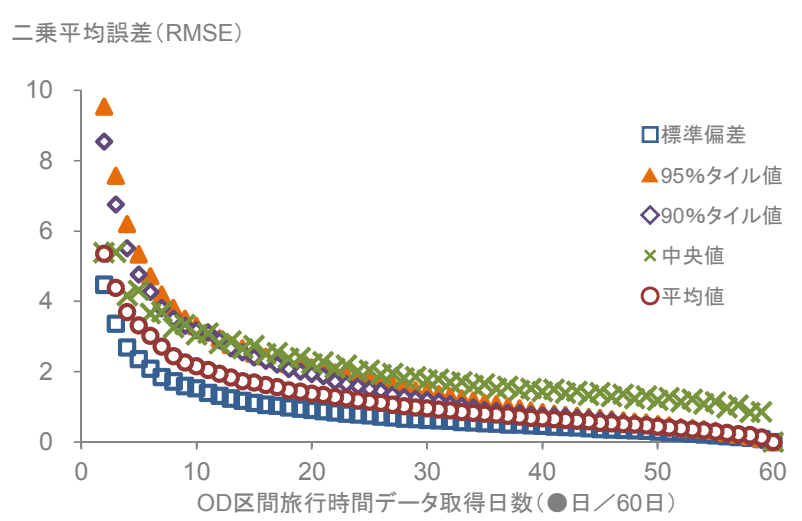

図-17 OD 区間旅行時間データ取得日数と二乗平均誤差 (RMSE) との関係 


\section{7. おわりに}

プローブ旅行時間データの取得状況と旅行時間信頼性 指標值の信頼度との関係を分析し，一定の信頼度で指標 を算定するために必要となるOD区間旅行時間データの 取得日数について, 次の知見を得た：

・旅行時間のばらつきの大きな区間では，一定の信頼 度で旅行時間信頼性指標值を算定するために必要な データ取得日数は多くなる.

・旅行時間のばらつきの大きな区間では，欠測区間長 割合が大きくなると，一定の信頼度で旅行時間信頼 性指標値を算定するために必要なデータ取得日数は 増加する。

- 評価対象日数が増加すると（20日 日 60 日 $\rightarrow 96$ 日）， 必要データ取得日数割合 ( “一定の信頼度で旅行時 間信頼性指標值を算定するために必要なデータ取得 日数”が “評価対象日数”に占める割合）は概敞減 少する.

本研究で得られた「一定の信頼度で旅行時間信頼性指 標を算定するために必要となるOD区間旅行時間データ の取得日数」等に関する知見は, 必要な追加検討を行っ た後，現在作成中の「時間信頼性指標值算定マニュアル

(DRM区間単位のプローブ旅行時間データから指標值 を算定する手順を解説）」に反映させることとしている. 今後, 事業実施効果の評価をはじめとする種々の実務の 場面で旅行時間信頼性指標を用いる際，「その旅行時間 信頼性指標值がどの程度の信頼度を有するか」といった 基礎情報を実務担当者に提供する資料として活用される ことを期待する.

謝辞 : 本研究を進めるにあたり，「交通工学研究会『実 用的な旅行時間信頼性指標に関寸る展開研究（代表 : 東 京工業大学 朝倉康夫教授）』」から，丁寧か力熱心な ご指導を賜りました。ここに感謝の意を表します.

\section{補注 標本データセット数}

3 章(1)では, 標本データセットの数を 1,000 としてい る. 以下にこの根拠を示寸. データ取得日数の組み合わ せは最大で約 $12 \times 10^{16}$ (60 日のうち 30 日分のデータが 取得できたケースの ${ }_{60} \mathrm{C}_{30}$ ) となる. $12 \times 10^{16}$ とおりの標 本データセットを作成することは現実的でないことから， 式(4)を用いて分析に用いる標本データセットの数を設 定した ${ }^{11)}$.

$$
e=\alpha \sqrt{((N-n)(N-1))(p(1-p) / n)}
$$

$n$ : 必要な標本データセット数

$N$ : 母数

$p \quad:$ 標本比率

$\alpha$ : 信頼度係数

e : 標準誤差率

標本データセットから算定した旅行時間信頼性指標値 が真值の一定範囲内に入るか否かを判定基準としたため, 標本比率 $p=0.5$ とした. 信頼度は $95 \%$ や $99 \%$ を用いる のが一般的であり, より厳しい信頼度 $99 \%$ の信頼度係 数 $\alpha=2.81$ とした. 標準誤差率 $e$ は交通関連調査では 20\%とされることが多いが，より厳しい $5 \%$ とした. 母 数 $N=12 \times 10^{16}$ として式(4)から標本データセッ卜数を求 めると $n=790$ となった. 安全側をみて, 必要な標本デー タセット数を 1,000 とした.

\section{参考文献}

1) 財団法人日本デジタル道路地図協会 : 全国デジタル 道路地図データベース標準，第 3.8 版，2008.

2) 日下部貴彦, 井料隆雅, 朝倉康夫 : 出発時刻選択と 旅行時間信頼性, 土木計画学研究・講演集, Vol.37, CD-ROM (No.127), 2008.

3) 国土交通省中部地方整備局: 名二環（名古屋南 JCT ～高針 JCT）国道 302 号開通 6 ケ月後の交通状況, http://www.cbr.mlit.go.jp/kisya/2011/11/1128.pdf, 2011.

4) 国土交通省四国地方整備局：国道 56 号宇和島道路の 開通 1 年後の効果について, http://www.skr.mlit.go.jp/ oozu/kisya/pdf_h23_kisya425.pdf, 2011.

5) 新東名(静岡県)インパクト調整会議ホームページ, http://www.shintomei-shizuoka.net/impact.html

6) 有吉亮, 中村文彦, 岡村敏之, 矢部努 : 期待值の信 頼区間を考慮した旅行時間データの取得技術に関す る研究, 土木計画学研究・講演集, Vol.32, CD-ROM (No.185), 2005.

7) 姚恩健, 藤田貴司, 佐藤彰典: 交通情報生成におけ る最小サンプルデータに関する研究, 第 5 回 ITS シ ンポジウム 2006 Proceeding, pp.243-248, 2006.

8) Quiroga, C. and Bullock, D. : Determination of Sample Sizes for Travel Time Studies, ITE Journal, Vol. 68, No. 8, pp. 92-98, 1998.

9) 橋本浩良, 河野友彦, 間間俊幸, 上坂克巳: 一般車 プローブデータの集計対象期間と旅行速度の推計精 度の関係分析, 土木計画学研究・講演集, Vol.42, CD-ROM (No.156), 2010.

10) 若林拓史 : 各種旅行時間信頼性指標の比較と課題, 土木計画学研究・講演集, No.37, CD-ROM (No.118), 2008.

11) 総務省政策統括官(統計基淮担当)監修: 統計実務基礎 知識一平成 20 年度版一, (財)全国統計協会連合会, 2008.

(2014. 2. 28 受付) 


\title{
RELATIONSHIP BETWEEN VOLUME OF PROBE DATA AND ACCURACY OF TRAVEL TIME RELIABILITY INDICES \\ - HOW DOES A PARTIAL DEFICIT IN PROBE DATA INFLUENCE THE ACCURACY OF TRAVEL TIME RELIABILITY INDICES?
}

\author{
Hirotaka SEKIYA, Keiji MOROTA and Susumu TAKAMIYA
}

Using probe car data obtained for two OD sections $(31 \mathrm{~km}$ and $19 \mathrm{~km})$ on a national highway over one year, we demonstrate the relationship between volume of probe car data and accuracy of travel time reliability indices calculated from them. Specifically, we create, as sample data sets for testing, OD travel time data sets with partial deficits that lack travel time data for some sections of all OD sections and for some days during evaluation periods. Then, we examine the difference between travel time reliability indices derived from OD travel time data sets with partial deficits and travel time reliability indices derived from those without partial deficits. As a result, we clarify the volume of probe car data required to calculate travel time reliability indices with a certain level of accuracy. 